\title{
Surfaces
}

\section{"DOING JUSTICE TO FEMINISM"}

\section{Diane Elam}

Volume 2, 1992

ACTES DU COLLOQUE « REPENSER LA CULTURE » ACTS OF THE CONFERENCE "RETHINKING CULTURE"

URI : https://id.erudit.org/iderudit/1065228ar

DOI : https://doi.org/10.7202/1065228ar

Aller au sommaire du numéro

\section{Éditeur(s)}

Les Presses de l’Université de Montréal

ISSN

1188-2492 (imprimé) 1200-5320 (numérique)

Découvrir la revue

Citer ce document

Elam, D. (1992). "DOING JUSTICE TO FEMINISM". Surfaces, 2.

https://doi.org/10.7202/1065228ar

\section{Résumé de l'article}

La relation entre le féminisme et les études culturelles, avec un accent particulier sur le féminisme en tant que " projet culturel ». d'utilisation que vous pouvez consulter en ligne.

https://apropos.erudit.org/fr/usagers/politique-dutilisation/ 
CONFERENCE PROCEEDINGS

"RETHINKING CULTURE"

"DOING JUSTICE TO FEMINISM"

Diane Elam

This paper was originally delivered at the conference Rethinking Culture held at the University of Montreal, April 3-5, 1992. The organizers would like to thank the following sponsors for their financial support:

Social Science Research Council of Canada

Faculty of Arts and Sciences, University of Montreal

Vice Rector for Teaching and Research, University of Montreal

Department of Comparative Literature, University of Montreal

Alitalia

ABSTRACT

The relationship between feminism and cultural studies, with particular reference to feminism as a "cultural project". 


\section{RÉSUMÉ}

La relation entre le féminisme et les études culturelles, avec un accent particulier sur le féminisme en tant que "projet culturel".

Cultural studies has been hailed as where we go next, a post-poststructuralism that will return us to a new politics, leaner and fitter after a refreshing bout of deconstructive doubt. Within this scenario critical thought goes back to basics, having learned to be suspicious of binaries, but no longer needing to worry itself with needless complexity. Following this regime, some feminists have hailed cultural studies as a political rescuer from the perplexing difficulties of a deconstruction that they understand as a male science. I hope that I do not sound too flippant when I say that this is not a very interesting argument to spend much time over, since it is too easy to fall into caricature on either side: attacking feminism as anti-intellectual, or deconstruction as patriarchal. Let me just say that feminism is not antiintellectual: if thinking the body is not purely cerebral, it is nonetheless thinking. Nor is deconstruction sexist. I would go so far as to suggest that much of what counts in feminism today owes an all-too-often unacknowledged debt to the way in which deconstruction allows us to understand the gender binary.

So I don't think that cultural studies comes to rescue feminism. The work of rethinking the political, as far as feminism is concerned, does not occur because cultural studies provides some kind of political life preserver. Rather, I want to argue for a polemical version of both feminism and cultural studies, which will lead us to understand more clearly the kind of political rethinking, the kind of cultural transformation, that is taking place, that has taken place, in the name of feminism. Put simply, feminism's rethinking of the political necessarily involves a rethinking of culture. And that rethinking is not a matter of finding a new identity for women.

In these terms, feminism is neither simply a part of culture (inside it) nor another, parallel, women's culture. Deconstruction is crucial for me in thinking this difficult relationship between feminism and culture, in working out how to maintain at the same time a critique of exclusion from male culture and a refusal of simple incorporation or assimilation within the patriarchal structure. Deconstruction, that is, will allow me to plot the 
extensive trouble of the feminist supplement to culture, the way in which woman stands on both the inside of the outside (within exclusion) and the outside of the inside (beyond inclusion).

The place of feminism in rethinking culture is a complex one. On the one hand, woman has not been thought in culture in the first place; she is the unthought of culture. On the other hand, feminism is rightly suspicious of situating woman as simply a deficiency which culture will have to make up, another lack or gaping hole to be filled. What I want to do in this talk is to try to work out what is at stake in the institutional development of cultural studies and to see what parallels there are between this and the institutional inscription of feminism. On that basis, I want to propose that feminism is as much in need of rethinking as culture. However, and it is very important to understand this, cultural studies and feminism do not just rethink culture and woman once and for all. Their importance, their shared importance, is that in their better moments they manage to situate both culture and woman as instances that always demand to be rethought. That is their task, their honor; it is, alas, a task more often honored in the breach than in the observance in the academy today.

So what is culture? What are cultural studies? And are all studies of culture, cultural studies? First, defining culture. While this is not exactly the space in which to offer up an exhaustive history of the term "culture" -- I do want to sketch some different possibilities for what "culture" might mean. My emphasis today is distinctly Western centered, although this is more owing to my desire to engage with the North American and European accounts of cultural studies, within a very limited space, than to any principle of exclusion.

With this in mind, I want to begin by recalling Walter Benjamin's remarks about "culture" in his "Theses on the Philosophy of History." Benjamin defines culture in terms of cultural treasures, which are best understood as the spoils of the victors. As he puts it:

Whoever has emerged victorious participates to this day in the triumphal procession in which the present rulers step over those who are lying prostrate. According to traditional practice, the spoils are carried along in the procession. They are called cultural treasures ...[1]

While more recent pundits like Alan Bloom want to organize a celebration of this storehouse in their attempts to turn our attention to a full scale inventory of the contents, Benjamin is more skeptical about theories of cultural worth or worthiness. In fact, his observations lead to what is now 
his famous conclusion that "there is no document of civilization which is not at the same time a document of barbarism."[2]

Benjamin's skepticism of the value of high culture does not mean that there is necessarily a more liberating range of possibilities to be found in mass or popular culture. In the Dialectic of Enlightenment, Adorno and Horkheimer argue that mass culture is little more than a "culture industry" of entertainment that ensures obedience to the social hierarchy.[3] According to them, as "the whole world is made to pass through the filter of the culture industry," the result is "a constant sameness" that crushes all insubordination.[4]

In contrast to the cultural pessimism of the Frankfurt school, Raymond Williams's insistence on community sounds a positive note for leftist thinking on culture. For Williams, culture is not just Arnoldian "high culture" or Benjamin's spoils of the victor, and it includes a notion of common cultures which are not simply Adorno and Horkheimer's pernicious culture industry. The idea of culture, according to Williams, becomes "a general reaction to a general and major change in the condition of our common life."[5]

So where does this leave feminism? If we follow Benjamin's lead, then feminism would be left without culture, insofar as feminism has yet to win its battle with patriarchy for the unquestioned possession of the treasures of high culture. Following Adorno and Horkheimer, feminism would be an appeal to precisely those marginal areas of the culture industry to which they devote so much scorn when they refer to the "puritanism of women's movements, " the demand for "rubbish" in the form of "the idiotic women's serial," and "the monotony of the sexual symbolization of female film stars. [6] Finally, as far as William's definition of culture is concerned, feminism would have an undefined relationship to the framework of Marxist class analysis.

In spelling out these possible positions, I do not want to go on to suggest a unifying perspective from which feminism can view culture, can decide whether or not "culture" is a good or a bad thing. But I do want to proceed in a direction which can begin to articulate feminism's relationship to "culture." And in order to do this I want to turn to a rather unlikely source: a brief remark that Wittgenstein made, a note found among his manuscript material at his death. Wittgenstein remarked that:

Culture is an observance. Or at least it presupposes an observance.[7] 
Observance here is to be understood in the sense of religious observance, as a rule of order, Ordensregel. However, I want to take advantage of an ambiguity that arises in the English translation to sketch the problematic of cultural studies. For an indigenous British sociology owes much to the development around World War II of a practice of mass sociology which was of crucial importance to the foundation of the postwar welfare state. Under the title of "mass observation," a group of left-wing social critics in Britain developed sociological techniques of survey designed to affirm that the working classes did, in fact, possess an autonomous culture -- of football matches, women's groups, pub-going, etc. This preliminary displacement of the boundary between high and low culture, this refusal to identify mass society as simple lack of culture begins in a practice of observation, a practice of which we, as readers of Foucault, have come to be justly suspicious.

However, to return to Wittgenstein, I want to underline that if culture is observance, we should perhaps hear a double meaning. On the one hand, a sociological observation. On the other hand, a work of faith, of participation and belief, a community in Williams's terms. As observation, culture is society. As observance, culture is community. My sense is that this double meaning is the endemic question of cultural studies -- of what cultural studies is.

Something like this ambiguity can be found even in the way of cultural studies that names a specific British project of Marxist literary and historical analysis, which for thinkers like Raymond Williams, E.P. Thompson, and Stuart Hall implies an explicit rejection of the rigid economic determination of the superstructure by the base. In this sense, "cultural studies" defines itself as a revisionary movement within Marxism, as an alternative to the theoretical rigidity of European Marxism. Thompson's mockery of Althusser in The Poverty of Theory is an overt example of what I'm talking about.[8] But this openness shouldn't blind us to the consistent problem of selfdefinition in cultural studies, something which the importation into the United States tends to obscure.

There is a certain tendency in the American academy to police what is and what is not allowed to be called cultural studies. I can think of no better example of this than Cary Nelson's essay "Always Already Cultural Studies: Two Conferences and a Manifesto." [9] On the one hand, Nelson stresses that cultural studies is not suppose to have a fixed methodology, although it does have no less than fourteen different points to which it ideally adheres. On the other hand, despite his claims for the variety of shapes that cultural studies can take, Nelson seems to have a very firm (and fixed) idea of just what does and does not constitute cultural studies. Thus, he takes to task a number of people for believing that they are doing cultural studies when they are not following the tradition that Nelson has in mind. To present an 
abbreviated version of Nelson's criteria, it is very clear that failure to place one's work in relation to British cultural studies is grounds for refusing to grant the trademark "cultural studies." In short, for Nelson, "cultural studies" must be articulated in relation to its history and that history must always be British. Vincent Leitch recognizes the problem here when he makes a remark that Nelson both quotes and all too quickly dismisses. Leitch rightly observes that he "thought we had thrown off the yoke of the British two hundred years ago."[10] Indeed, there is a curious colonial allegiance in Nelson's stringent -- even strident -- defense of a strictly British heritage for cultural studies.

To get a clearer sense of the limits of Nelson's argument, apart from its British dimensions, I want to turn to one last remark from his essay. Nelson chides a job interview committee for asking their candidate (his student) what cultural studies are. Presumably the point is that this unnamed group of academics should have known the answer to their own question (and thus have not needed to ask it) before they went out looking for someone to perform the required service of Assistant Professor of Cultural Studies. But unlike Nelson's analysis of the situation, it strikes me that this committee has, for whatever reason, hit on what is at stake in the study of culture: that what culture is and what the study of culture might entail is open to question, is a question which no notion of cultural studies can claim to settle. In that sense, I think Nelson's assumption that not all studies of culture are cultural studies sets up an unnecessary boundary.[11] That both Nelson and Alan Bloom would claim to be studying culture -- with dramatically different ends in mind -- would seem to me to indicate what is at stake in the study of culture. It is not the case that one is simply right and the other wrong, but I am also not arguing that their disagreement makes no difference. If I have more sympathy in the long run with Cary Nelson than with Alan Bloom, it's because the former leaves the question of culture more open than Bloom does, although Nelson's weakness is at times to want to slip into being a left-wing Alan Bloom. To put this another way, culture is what hurts, and we shouldn't try to bandage that wound, repanser la culture, to close down discussion. Thus, for feminism, the implications of policing efforts like Nelson's -- which are done in the name of progressive politics -- stand to have the opposite effect of that which he tries to claim.

In response to this serious problem, I want to return to Adorno and Horkheimer's work. While I do not share their deep suspicion of popular culture -- as a feminist I think that would be remarkably difficult to do -- I would, however, like to suggest that a rephrasing of their argument can be used to sound a cautionary note that cultural studies, the study of culture, should not itself become another name for, another branch of, the culture industry. To take a few editorial liberties with Adorno's and Horkheimer's prose, we should do well to remember that: 
[Cultural studies] can pride itself on having energetically executed the previously clumsy transportation of art into the sphere of consumption, on making this a principle, on divesting amusement of its obtrusive naïvetés and improving the type of commodities. The more absolute [cultural studies] became, the more ruthless it was in forcing every outsider either into bankruptcy or into a syndicate, and became more refined and elevated -until it ended up as a synthesis of Beethoven and the Casino de Paris.[12]

Keeping in mind Adorno's and Horkeimer's warning, what I want to suggest now is a more or less three fold parallel between the problematic of cultural studies and that of feminism, by virtue of which culture and feminism become tasks of rethinking. First, there is the obvious analogy by which the gender opposition male/ female is interrogated along with that between high/low culture, margin/center, western/non-western. However, feminism isn't just one item on a list; it is, secondly, an important element in the critical enframing of the everyday. Benjamin says of cinema that like Freud's Psychopathology of Everyday Life, it turns everyday behavior, which might otherwise pass unnoticed, into an object of analysis.[13] It seems to me that this is the best way to understand the pressure of so many feminist struggles about nomenclature, the hoary chestnuts of "spokesperson" and "letter carrier" in English. Feminism shares this critical attention to the everyday, and its historical close association with film studies is perhaps best explained in Benjamin's terms. The third analogy I want to draw concerns the putting in question of this critical distance. To return to my pun on observance, feminism shares with cultural studies the fact that it is divided between observation of and participation in culture. Women in the transformation of culture both transform culture and are transformed along with it, are both actors and acted upon. The lesson that I want to draw here for feminism is that this double articulation of both implication and critique necessitates a ethical turn if we are to do justice to feminism, if feminism is to be more than merely a part of the general sociology of culture.

Cultural studies has at times given up the attempt to elaborate the resistant and excessive materiality of actual cultural practices in favor of merely sneering at bourgeois empiricism hopelessly seduced by ideology. The term "cultural studies" has always had an ambiguity in excess of the sociological sense, "the study of culture." "Cultural studies" mean that our studies themselves are cultural, that there is no position of theoretical anonymity from which we can simply decry ideological error or lack of philosophical rigor. In ceasing to think about subjectivity in terms of identity, ideology in terms of falsification, we do not abandon critical discourse; rather we shift out of a merely negative or reactive understanding of resistance as inherently oppositional.

In arguing for the necessity of rephrasing feminist action in terms closer to the traditional discourse of ethics than to conventional understandings of 
the political, it would seem to me that what we stand to learn from feminism is that there are problematic positions about which we cannot speak a single political truth. That is to say, the strength and power of feminism comes from not being a single politics that is articulated every where at every time in the same way. This is not to abandon politics or make claims for cultural as apolitical. That culture is apolitical has, of course, been a long-standing conservative claim. Conservatives frequently tautologically claim that their idea of culture is based purely on "culture", while leftist dissenters have politics and ideology as the grounds for their cultural judgments. In response,I would argue, not surprisingly, that there is a politics to claiming that culture is not political.

However, a discussion of the political nature of culture only gets us so far in that feminism is not a political metanarrative in the way Marxism, for instance, is. To speak of a feminist politics (or of $a$ single feminist ethic for that matter) is not to recognize the diversity and division within feminism, is not to listen to the many voices in which feminism can be articulated. Polyphony has been a strong feature of feminist writing for some time. Rather than appealing to identity or unity as a way of bringing, together women's voices, polyphony may suggest that solidarity need not rest on an underlying identity or an overarching unity. The defense and advancement of feminist concerns will require more subtle theorization than the successful call to identity of the 60's and 70's. Feminine identity was a gain; it may now prove too slow moving, too easy a target, if "justice" is to become something more than the honorary title accorded to feminism's enemies -- as in "Justice Thomas". What this means for "culture" is that there is no appeal to cultural unity, no foundational claim with empirical grounds. Culture is the ethical name feminism gives to groundless solidarity, a solidarity which is polyphonic, if not always harmonious.

In raising the issue of ethics, by returning to the problem of what it would mean to do justice to feminism, I think it is necessary to explain how I am using -- or rather not using -- the term "ethics." First, my intention here is not to postulate an ethics of care, where somehow women, and hence feminism, can offer culture a kinder, gentler world on the basis of some inherent feminine goodness.[14] That is to say, I am not proposing a feminist rewriting of the Aristotelian "good life," where this time true friendship is between women, who contemplate ethos and find the highest eudaimonia.

Second, I do not wish to become a spokesperson for the moral status quo a la Hume, who turns to a combination of utility and sympathy as the basis for understanding given moral rules, which he assumes are so obvious that they need not be interrogated. In fact, I would go so far as to suggest that in some sense this is the danger of the feminist anti-porn movement. Anti-porn feminists, as Laura Kipnis points out, are trying to construct a politically 
correct notion of femininity against other "'unreconstructed' versions." The danger here is that feminism, to borrow Kipnis's words again, threatens to be reduced to "another variety of bourgeois reformism" in which "the policing of popular representation seems like only a path to more domination."[15]

Third, I also do not want to propose that justice is a calculable commodity in the fashion of utilitarian philosophies. Ethics is not something that the moral person simply recognizes so as to understand that immorality doesn't pay. I would strongly suggest that ethical consequences are precisely not decidable --calculated once and for all; statistical inference should not be understood as a final judgment.

Having said how I do not want to consider ethics, I now want to explain what it is I would like to do. My understanding of ethics is perhaps closer to Kant in that I want to emphasize an ethics of duty and obligation, rather than an ethics of care, of the good, or of the useful. However, I am in no sense a strict Kantian, pleading the case for a moral a priori, a metaobligation to be moral, which issues from a higher, divine power. The ethical obligation of and to feminism in the realm of culture is not a categorical imperative, an observance by a subject of a transcendental moral law.

Ethics here names an approach to the problem of doing justice, which acknowledges the radical contingency of discursive pragmatics. And this matter brings me back to the relationship between deconstruction and feminism. If, as Derrida suggests, "there is a duty in deconstruction" and if there is also a duty in feminism, to whom or to what is this duty owed? The question is not merely academic to the extent that duty must exceed the walls of the academy.[16] The location of that obligation is not something to be determined. It is this sense of the indeterminate that enforces an ethical judgment. Since that whose call we must answer cannot be identified, there are no original grounds which can serve as a model for future judgments. To use Derrida's words once again, "the origin of the call ... comes from nowhere ... Something of this call of the other must remain nonreappropriable, nonsubjective, and in a certain way nonidentifiable, a sheer suposition, so as to remain other, a singular call to response or responsibility."[17] The duty of feminism, then, is a duty to sexual difference, that in effect, comes from nowhere. I say "comes from nowhere" in the sense that it is an ontological fact onto which meanings may subsequently be grafted, meanings that it has been the business of feminism to contest. However, as ontological fact, it exceeds any meaning that might attempt to explain it, to do away with it. Feminism, that is, is not about establishing the true nature of sexual difference - -- either inside or outside of culture -rather it is about keeping sexual difference open as the space of radical uncertainty. We do not yet know what woman can do and the paradoxical thing about women is that they produce energy to act as cultural transformers. No Nukes. 


\title{
Diane Elam
}

\section{Department of English}

\author{
Indiana University
}

$\underline{\text { Surface Page d'Acceuil/Home Page }}$

[1]Walter Benjamin, "Theses on the Philosophy of History," Illuminations, tr. Harry Zohn (Great Britain: Jonathan Cape Ltd., 1970), 258.

[2]Benjamin, "Theses on the Philosophy of History", 258.

[3]Theodor Adorno and Max Horkheimer, Dialectic of Englightenment, tr. John Cumming (London: Verso, 1979), 134, 147-48.

[4]Adorno and Horkeimer, Dialectic of Enlightenment, 126, 134.

[5]Raymond Williams, Culture and Society 1780-1950 (London: Chatto and Windus, 1958), 295.

[6]Adorno and Horkheimer, Dialectic of Englightenment, 141, 152, 138.

[7]Ludwig Wittgenstein, Culture and Value. ed. G. H. Von Wright with Heikki Nyman, tr. Peter Winch (Chicago: The University of Chicago Press, 1980), $83 \mathrm{e}$.

[8]E. P. Thompson, The Poverty of Theory and Other Essays (London: Merlin Press, 1978).

[9]Cary Nelson, "Always Already Cultural Studies: Two Conferences and a Manifesto," Journal of the Midwest Modern Language Association, 24 (1), 24-38.

[10]Quoted in Nelson, "Always Already" 25.

[11]Nelson makes this point clear in his co-written introduction to the weighty volume, Cultural Studies (Cary Nelson, Paula Treichler, and Lawrence Grossberg, "Cultural Studies: An Introduction," Cultural Studies, ed. Nelson, Treichler, and Grossberg [New York and London: Routledge, 1992] 10). 
[12]Adorno and Horkheimer, Dialectic of Enlightenment, 135.

[13]Benjamin, "Art in the Age of Mechanical Reproduction," Illuminations 237-8.

[14]On this count, I am certainly taking my distance from the work which follows in the wake of Carol Gilligan's In A Different Voice (Cambridge, Mass.: Harvard University Press, 1982).

[15]Laura Kipnis, "Reading Hustler," Cultural Studies 388-89.

[16]Jacques Derrida, "'Eating Well,' or the Calculation of the Subject: An Interview with Jacques Derrida," tr. by Peter Connor and Avital Ronell, Who Comes After the Subject, ed. Eduardo Cadava, Peter Connor, Jean-Luc Nancy (Routledge, 1991), 108.

[17]Derrida, "Eating Well", 110-11. 